\title{
隣接する地下水流域間の地下水流入出に関する研究
}

\author{
齋藤晴紀 $^{1} \cdot$ 酒井一人 $^{2} \cdot$ 籾井和朗 $^{3} \cdot$ 中村真也 $^{4}$
}

\section{Study on the Flow of Groundwater between Adjacent Groundwater Basins}

\author{
Haruki Saito ${ }^{1}$, Kazuhito Sakai ${ }^{2}$, Kazuro Momii ${ }^{3}$ and Nakamura Shinya ${ }^{4}$
}

\begin{abstract}
This study examined the geological structure and groundwater flow at the basin boundaries in Shirakawata basin and Higashi-soedo basin, the basin of main drinking water source of Miyako Island. From the results of the boring survey and the vertical electrical sounding, in northwestern part of Shirakawata basin, it was found a new continuous of groundwater with adjacent Higashi-soedo basin. In the northern part and northwest part of Higashi-soedo basin where the connection was pointed out with the adjacent basin, the situation was confirmed, and more detailed aquifer shape was revealed. Also, it became clear that the groundwater flowed out to the adjacent basin at these basin boundaries from the slope of groundwater surface in the vicinity. We estimated the outflow amount at these basin boundaries, from the cross sectional area of the outflow part, the hydraulic gradient of the groundwater, and the coefficient of permeability.
\end{abstract}

Keywords: groundwater flow; groundwater basin boundaries; aquifer; Ryukyu limestone; Miyako Island

\section{1 はじめに}

沖縄県宮古島では地形が平坦で, また, 透水性の高い 琉球石灰岩が地表付近に分布するために, 河川が形成 されにくく, 生活用水のすべてを地下水に依存している. 主要な水道水源流域である白川田流域および東添道流 域(図1)には, 海岸沿いの湧水を取水している白川田水 源 (湧水量: 約 $22,000 \mathrm{~m}^{3} /$ 日（宮古島市上下水道部, 2016)）と, 地下水を取水している7つの水源がある(高野 水源, 大野水源, 袖山水源, 前福水源, 西底原水源, 底 原水源，添道水源）(宮古島上水道企業団，1996a）。

白川田流域および東添道流域の水文地質学的な構 造については古川 (1981), 沖縄総合事務局 (1982)など によって，その概要が明らかにされた.この時点では，こ の両流域は 1 つの地下水盆として連結していると考えら ており, 白川田水源は相当な余裕があると考えられてい た.

しかし，1993 年からの少雨傾向により，宮古島では上 水道事業開始 (1965 年) 以来初めて, 1994 年 1 月 3 月 に 70 日間の制限給水を経験した(宮古島上水道企業団， 1996a).これを契機として，1994 年から４ケ年にわたる宮 古島上水道企業団による詳細調査が行われた。(宮古島 上水道企業団，1995，1996b，1997，1998a，1998b）。 そ の結果, 白川田流域と東添道流域は独立した地下水流 域であるとされ, 一方で東添道流域は, 北方の西添道流 域, 北西方の平良流域との連結が指摘された。しかし,

1 鹿児島大学大学院連合農学研究科博士課程, Doctoral student, The United Graduate School of Agricultural Sciences, Kagoshima University, 1-21-24 Korimoto, Kagoshima 890-0065, Japan

2 琉球大学農学部教授, Professor, Faculty of Agriculture, University of the Ryukyus, 1 Senbaru, Nishihara, Okinawa 903-0213, Japan (Corresponding Author) E-mail:ksakai@agr.u-ryukyu.ac.jp

3 鹿児島大学農学部教授, Professor, Faculty of Agriculture, Kagoshima University, 1-21-24 Korimoto, Kagoshima 890-0065, Japan

4 琉球大学農学部教授, Professor, Faculty of Agriculture, University of the Ryukyus, 1 Senbaru, Nishihara, Okinawa 903-0213, Japan
地質構造や地下水位のデータは十分ではなく, 今後の 調査による裏付けが必要とされた。

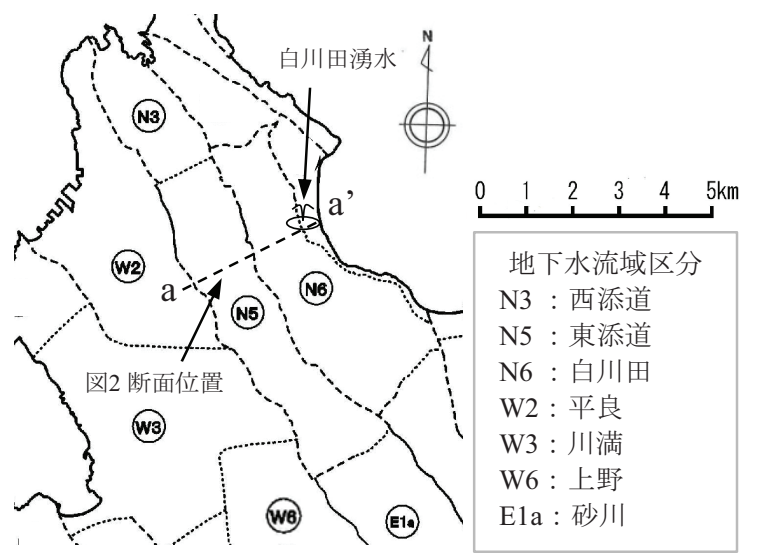

地下水流域界の分類と精度

— ：I（高精度で確定された断層位置等に一致する）

-----：II（断層あるいは不透水基盤の尾根により判断）

……… : IIII (不明確な不透水基盤の尾根により判断)

困 1: 白川田流域および東添道流域の位置（宮古島上 下水道部（2013）の地下水流域区分図を基に作 成)

なお，地下ダムが建設されている宮古島南部の砂川 流域では，国営事業における地下ダム建設にあたり，ボ ーリング調査: 約 500 地点, 垂直電気探査: 約 500 地点, 揚水試験:200 回以上が行われ(森ら，1997a，1997b), 地下水盆の構造および隣接流域との連結はないことなど が明確に判明している.これに対し, 水源開発事業など が行われていないことから，白川田流域および東添道流 域では, 地下水流域間の地下水流入出などを確定する 
調查および分析が十分に行われておらず，不明な点が 多い.

宮古島では, 近年, 水道水を隣の伊良部島一送水す ることが計画されており(宮古島市, 2011)，水道水源の 適切な管理体制の構築が必要となっている。このような 状況から,これまで調査が十分ではなかった白川田・東 添道流域の将来にわたって水道水源を管理する上で, 地下水流域界の位置や水循環を把握することの重要性 が高まっている.

そこで本研究では, 地質調査および地下水位観測を 実施し, 流域界における带水層の分布形状および隣接 流域一の地下水の流出状況について検討を行うとともに, 流出量の推定を行った.

本研究は, 宮古島の水道水源流域における水収支解 析や水道水源に関しての気候変動の影響評価, さらに は同様に琉球石灰岩が分布する地域の地下水流動の 推定など, 今後の研究に対して重要な知見を与えるもの であると考えられる.

\section{2 地形および水文地質}

\section{1 地形地質概要}

宮古島の地形は北西-南東または北北東-南南東方向の 断層に起因する多くの低山稯と南西方向へ緩く傾いたケ スタ地形で特徵づけられている.

宮古島の地質は下位より鮮新世〜更新世の島尻層群, 更新世の琉球石灰岩, 更新世～完新世と推定される大 野越粘土層が互いに不整合の関係で分布している. 島 尻層群は青灰色シル下岩から成り, 透水係数は $1 \times$ $10^{-7} \mathrm{~m} / \mathrm{s}$ 以下と難透水性を示し宮古島での水文地質学的 な基盤となっている(森ら, 1997a)。

琉球石灰岩は不圧地下水の帯水層となっており, 透 水係数, 有効間隙率については宮古島南東部の皆福地 下ダムでの調査結果では, ダム全体の平均透水係数は $3.54 \times 10^{-3} \mathrm{~m} / \mathrm{s}$, 有効間隙率は $10 \%$ と見積もられている (今泉ら, 1998).

\section{2 白川田流域}

白川田流域は北西〜南東方向へ長軸を持ち, 流域中央 部の基盤 (島尻層群) 上面の標高が低くなるすり鉢状を 成している(最深部の基盤上面標高: 約- $13 \mathrm{~m}$ ). 地下水 はその形状に応じ, 北側および南側から中央部に向かっ て流下し, そのほとんどが東縁海岸部で白川田湧水, お よび山川湧水として流出する. 白川田水源はこの 2 つの 湧水を水源としている.

白川田流域の西側は 30〜 60mの突出部を持つ低山 稜が北北東-南南東方向に延びている. その地下では東 落ちの正断層によって断層西側の基盤標高が高くなっ ており,これにより地下水は分断され, 白川田流域は西 方の東添道流域と分かれる(図2).

なお, 白川田流域の西側流域界北部においては, 断 層地形が不明瞭であり，また流域界付近の地質調查も少 ない. 地質構造については, 白川田流域内での垂直電 気探査の結果や島尻層群の露頭状況から, 付近には帯 水層である琉球石灰岩は分布しておらず, 大野越粘土 層の下位には直接基盤の島尻層群が存在すると考えら
れている(宮古島上水道企業団, 1998b).このため, 白 川田流域の西側流域界北部では, 流域界は南北の断層 の延長線上にある丘陵の尾根に設定されている.

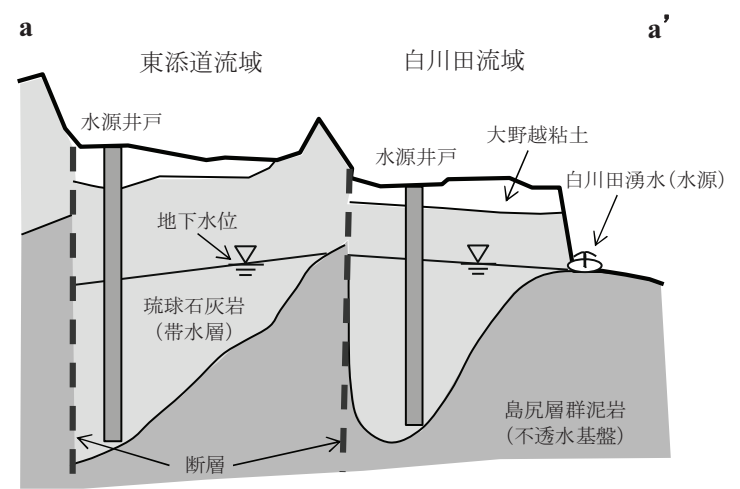

図 2: 白川田流域および東添道流域の模式地質断面 図（宮古島上水道企業団（1998b）の不透水基 盤等高線図を基に作成)

\section{3 東添道流域}

東添道流域は, 白川田流域同様に北西〜南東方向 一長軸を持つが，基盤上面の標高は北西部ほど低くな っており (最深部の基盤上面標高: 約 $-40 \mathrm{~m}$ ), 地下水は 南東から北西に向かって流下している.

東添道流域の西側は, 断層に起因した細長く延びる 低山稜によって, 北から平良流域, 川満流域, 上野流域 に接している.このうち, 平良流域との境界においては, 低山稜の尾根で行われたボーリング調査 1 地点で地下 水位が確認され, 2 つの流域の連結が指摘されている (宮古島上水道企業団, 1998a). また, 東添道流域の北 側も, 隣接する西添道流域との間に基盤の尾根等の分 水界は無く, 2 つの流域の連結が指摘されている.

宮古島上水道企業団 (1998b) では, これら東添道流 域の北側流域界, 西側流域界北部における帯水層形状, 地下水流向等を明らかにするためには, より詳しい調查 が必要としている.

\section{3 調査方法}

2009 年度および 2012, 2013 年度に, 現地にてボーリン グ調查, 垂直電気探查, 地下水位観測を実施し, その結 果から, 帯水層である琉球石灰岩や基盤の島尻層群の 分布状況, および地下水の流動状況を検討した.

\section{1 調査対象範囲}

本研究では, 他流域一の地下水流出の可能性が指摘さ れている3つの範囲 (白川田流域の西側流域界北部, 東 添道流域北部流域界, 東添道流域の西側流域界北部 (図 3))を対象とした.

\subsection{1 白川田流域の西側流域界北部}

白川田流域の西側流域界北部では, 地形的な段差や南 北の断層崖との連続性から, 約 $500 \mathrm{~m}$ の間隔で 2 列の断 層(図 3:A-A'，B-B'位置)が推定されていた.このうち 東側の断層沿いの尾根 (A-A'位置) がこの範囲での流 域界とされ, 地下水流域は隣接する東添道流域とは繋が っていないとされていた. 調査はこの 2 列の断層周辺で 
実施した(図 3).

\subsection{2 東添道流域の北側流域界}

東添道流域の北側流域界は, 地下水管理の観点から, 地下水塩水化のおそれのない位置として設定された経 緯があり, 带水層は隣接する北側の西添道流域と連続し, 地下水は西添道流域一流出していると考えられている. しかしながら, 東添道流域の北側流域界付近の地下水 位データは少なく, 地下水の流動方向や流出量につい て詳しく分かっていない. 調查はこの管理上の流域界付 近のうち, 帯水層厚が厚い西寄りの範囲で実施した (図 3).

\subsection{3 東添道流域の西側流域界北部}

東添道流域の西側流域界北部は, それまでは断層に伴 う基盤の高まりによって西側の平良流域とは分かれてい ると考えられていたが, 宮古島上水道企業団 (1998)の地 質調査によって, 断層に伴う基盤の高まりの一部に基盤 標高低い箇所が 2 箇所存在しており, 帯水層が西側の 平良流域と連続していることが判明した。 そして, そこか ら平良流域一地下水が流出していると推定された。

しかしながら, 調査データが少なく, 流出区間の幅や 流出量について詳しくは分かっていない. 調査はこの流 域界の尾根部 (G-G'位置; 断層上盤側) で実施した（図 3).

\section{2 ボーリング調査}

ボーリング調查は, 地下水流域界付近の帯水層である琉 球石灰岩の分布および基盤上面深度の確認を目的に
15 地点で実施した(図 3). 掘削後, ボーリング孔は観測 孔 (孔径:VP50mm, オールストレーナ)として仕上げ, 3.4 の地下水位観測にも利用した。

\section{3 垂直電気探査}

垂直電気探査は, 地層ごとの比抵抗值の違いを利用し て, 調查地点における深度方向の比抵抗分布から, 各 地層の深度を推定する手法である. 調查手法の簡便性 および経済性から広範囲の地質情報を効率的に得ること に適している. 宮古島に分布する琉球石灰岩と島尻層群 は比抵抗值に差があることから(図 4), 垂直電気探査は 基盤上面深度の確認において有効な手法とされている。 宮古島では, これまでに 1,000 地点以上の垂直電気探査 が実施されている.

本研究では, 主に基盤上面深度を把握することを目的 として 13 地点で実施した(図 3).

測定には「大地比抵抗測定器 Type-3244（横河電気 株式会社製)」を用いた。また，電極配置は深部の探 査の適応性に優れたシュランベルジャー法とし, 測定 記録から作成した $\rho-\mathrm{a}$ 曲線の解析には, Schlumberger 標準曲線と小野の補助曲線を用いた。

琉球石灰岩と島尻層群（不透水基盤）判定に当たっ ては, 図 4 より琉球石灰岩の下限值と島尻層群の上限 值が概ね $100 \Omega \cdot \mathrm{m}$ であることから，基本的には $100 \Omega \cdot \mathrm{m}$ 以下を島尻層群とした。ただし，近隣にボ ーリング調查結果のある地点 $(21 \mathrm{E}-9,21 \mathrm{E}-10,21 \mathrm{E}-11)$ については, ボーリング調査結果に合わせて, 最大で $200 \Omega \mathrm{m}$ 程度までを島尻層群として判定した。

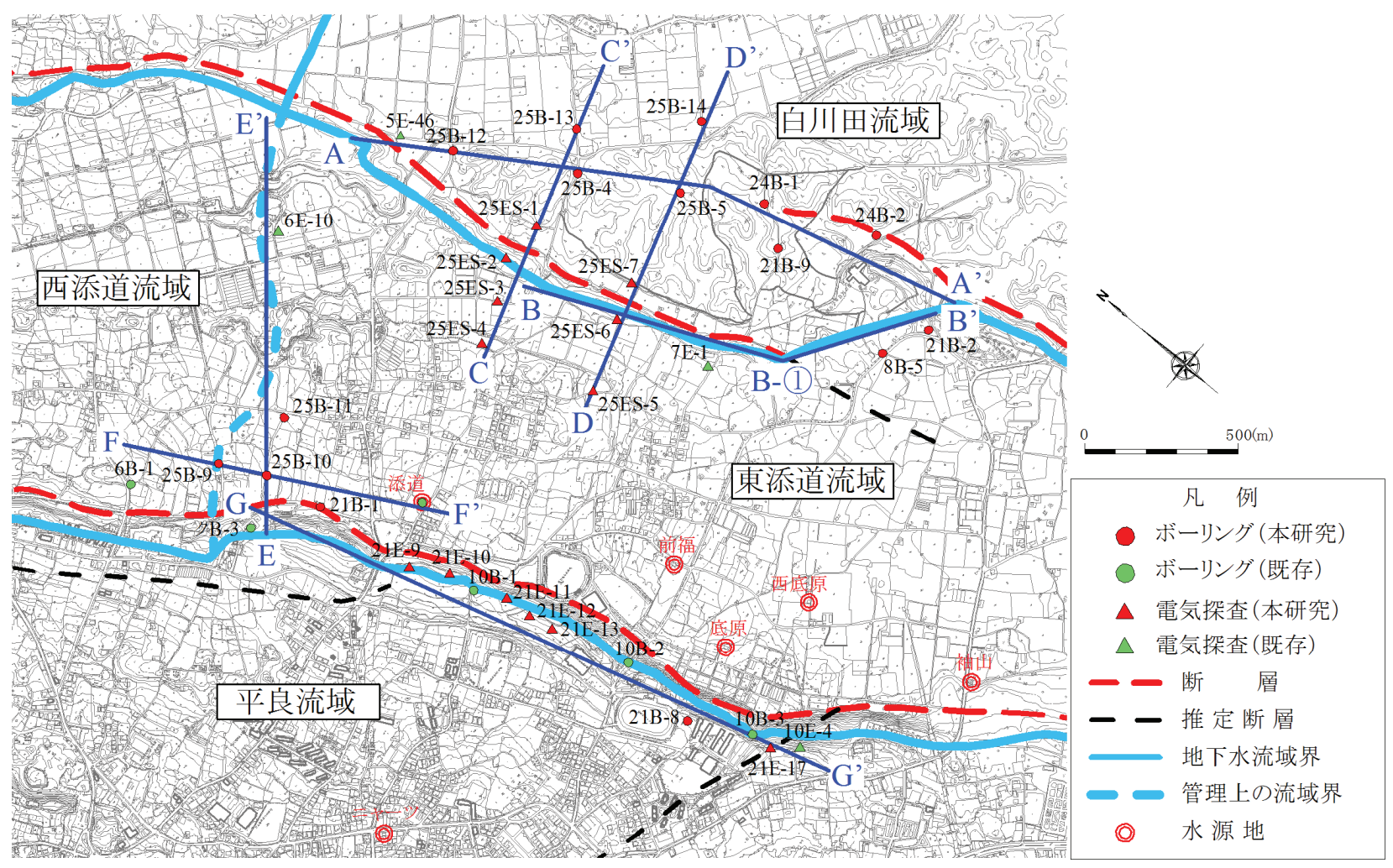

図 3: 調查位置（ボーリング調查，垂直電気探查）および地質断面位置（A-A 断面〜 G-G ${ }^{3}$ 断面） 

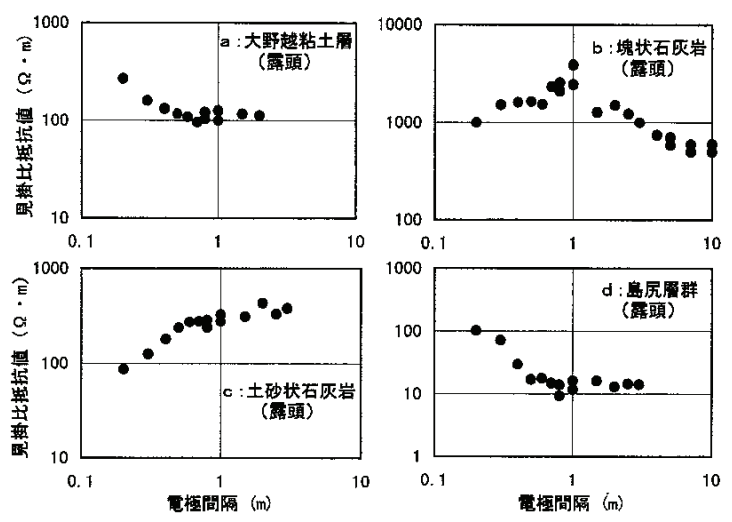

図 4：砂川流域における露頭での見かけ比抵抗值測 定結果（森ら，1997b）

\section{4 地下水位観測}

地下水位観測は，地下水流域界付近の地下水面形状 および動水勾配を把握するために, 周辺の地下水観測 孔や民家井戸(最大 34 地点)にて月 1 回(2013 年 1 月 〜 12 月) 実施した.

\section{5 流域界における流出量の推定方法}

本研究で明らかになった地下水流域界における帯水層 の断面積, 地下水の動水勾配をもとに, 以下のダルシー 式より流域界からの地下水流出量を推定した。

$$
Q=K A \Delta h / L
$$

ここで, $Q$ : 通過流量, $K$ : 透水係数, $A$ : 带水層の断面 積, $\Delta h / L$ : 動水勾配である. 帯水層の断面積としては, 流量推定断面における地下水面下の琉球石灰岩の断 面積を求めた. 動水勾配は各月の地下水位等高線図か ら流量推定断面に直交する動水勾配を求めた。 また, 透

水係数は付近の水道水源の井戸の揚水試験結果より 得られている值(表 1)を用いた。
表 1: 東添道流域および平良流域の揚水試験結果

\begin{tabular}{|c|c|c|c|}
\hline 流域名 & 水源名 & 透水係数 $(\mathrm{m} / \mathrm{s})$ & 相乗平均 $(\mathrm{m} / \mathrm{s})$ \\
\hline \multirow{2}{*}{ 東添道 } & 底原 & $4.13 \times 10^{-3} \% 1$ & \multirow{2}{*}{$2.26 \times 10^{-3}$} \\
\cline { 2 - 3 } & 西底原 & $1.24 \times 10^{-3} \% 2$ & \\
\hline 平良 & ニャーツ & $6.88 \times 10^{-2} \% 3$ & - \\
\hline
\end{tabular}

$※ 1$ 宮古島上水道企業団（1994a） ※2 宮古島市（2014） $※ 3$ 宮古島上水道企業団（1994b）

\section{4 結果および考察}

\section{1 白川田流域の西側流域界北部}

\subsection{1 流域境界部の地質構造}

図 5 は, 本研究のボーリング調査, 垂直電気探査(図 6) および既往調査結果から作成した流域界沿いの地質断 面図である。流域界沿い(A-A’断面)には，大野越粘土 層の下位に琉球石灰岩が分布し, 基盤上面の深度は深 い場所で標高 3.99m(25B-4)であった. 地下水位は標高 $15.77 \mathrm{~m}$ (25B-4:2013 年 9 月)であり, 帯水層は幅約 $1,500 \mathrm{~m}$ の範囲に存在し, 層厚は最大約 $12 \mathrm{~m}$ であること が判明した.さらに, C-C'断面, D-D’断面に示す通り, A-A 位置において白川田流域側と東添道流域側での 基盤上面標高の差は無く, 想定されていた断層構造は 存在しないと考えられた.

また, 東添道流域内の断層地形(B-B' 位置)を挟んで 実施した垂直電気探査では，北側の C-C’断面では基盤 上面に $22 \mathrm{~m}$ の差が見られるものの, 南側の D-D’断面で は大きな段差は見られなかった.よって, B-B’断面にお いては, 帯水層は幅約 $1,000 \mathrm{~m}$ の範囲に存在し, 層厚は 最大約 $10 \mathrm{~m}$ と推定された.

付近の地下水位は東添道流域側よりも白川田流域側 の方が高く(図 7), これは観測期間中, 同様の結果であ った.

これらの結果から,これまで流域界とされてきた A-A 位置, さらに, 西に $500 \mathrm{~m}$ の断層地形(B-B'位置)におい ても地下水面は連続しており,この範囲で白川田流域と
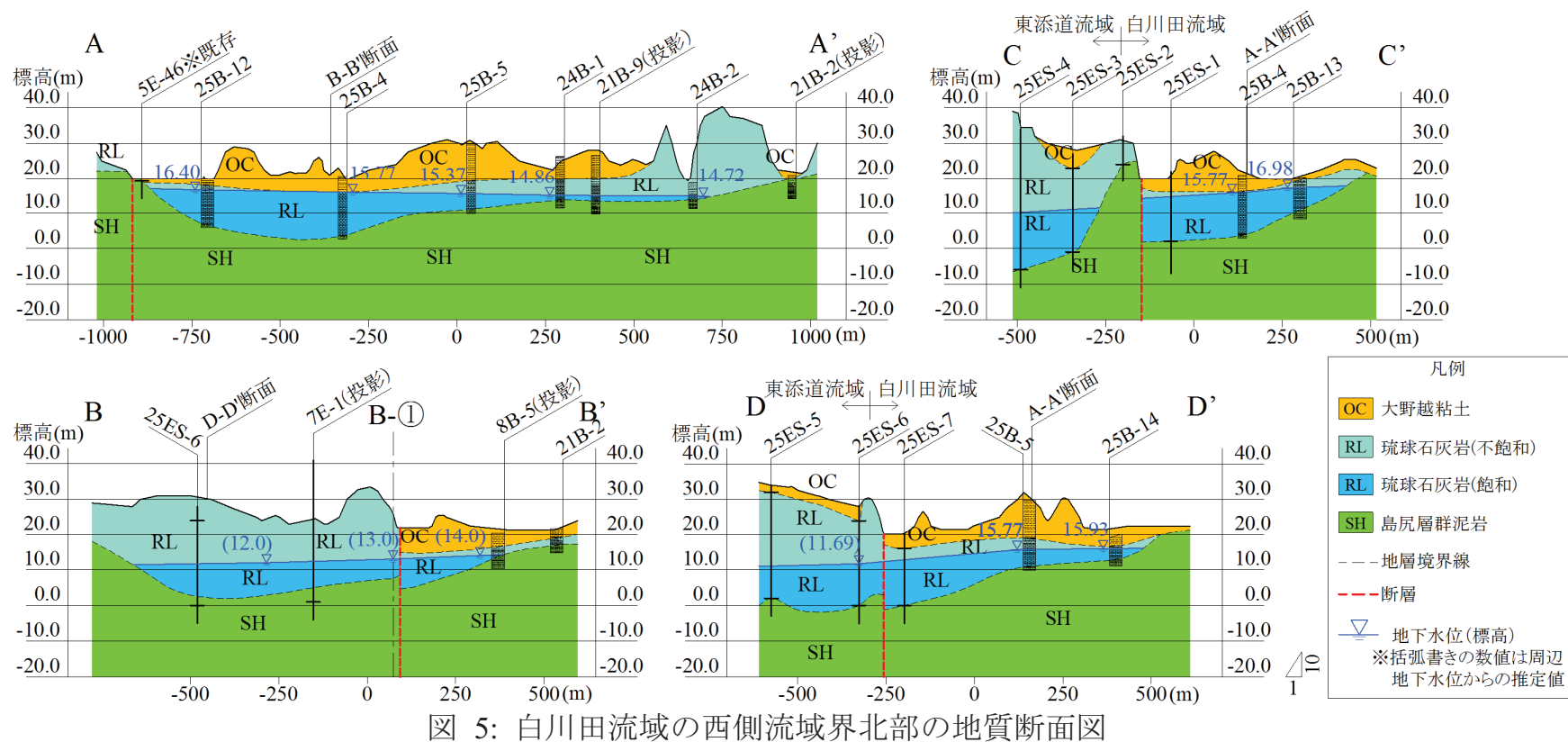

図 5: 白川田流域の西側流域界北部の地質断面困 


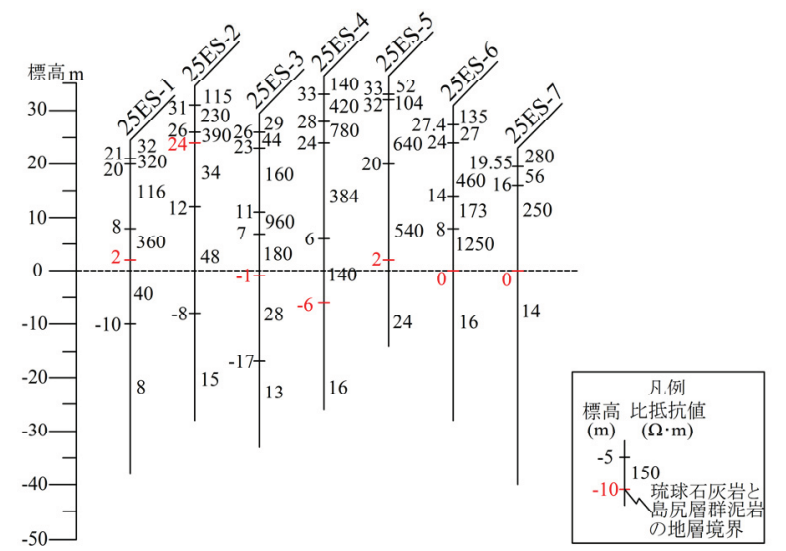

図 6: 白川田流域の西側流域界北部の垂直電気探査 結果柱状図

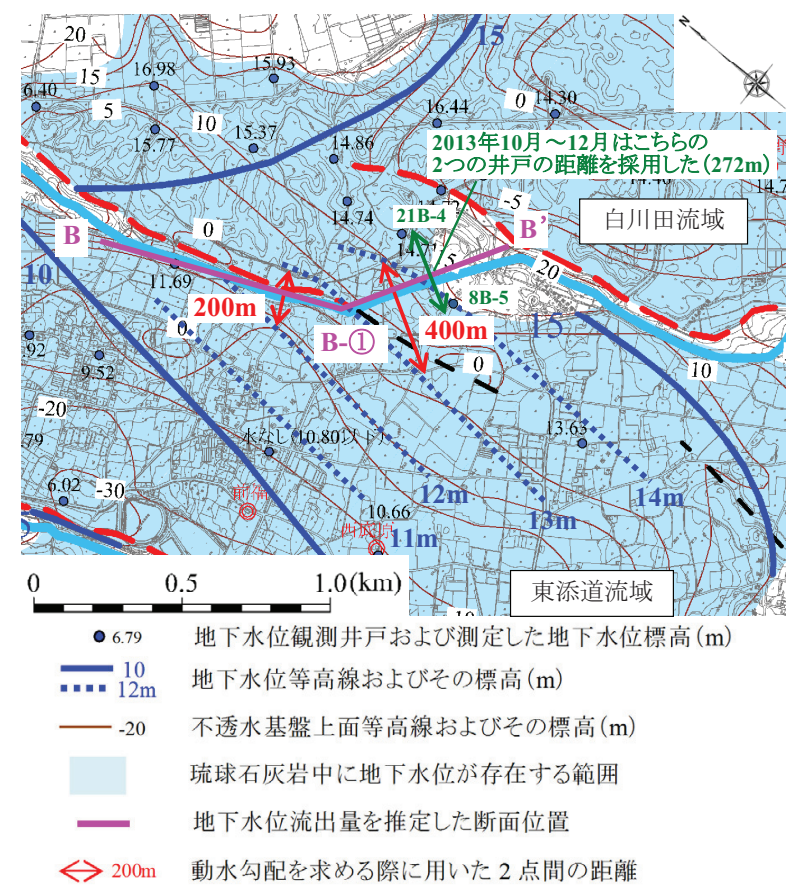

図 7: 白川田流域の西側流域界北部の地下水位等高 線図（2013 年 9 月 19 日）
東添道流域は繋がっていることが明らかになった。地下 水面の傾斜からは，地下水は白川田流域から東添道流 域へ流出していると考えられる.

\subsection{2 白川田流域から東添道流域への地下水流出量}

ここでは, 断層位置である B-B’断面を地下水流域界とし て, この断面における地下水の移動量 (白川田流域から 東添道流域への地下水流出量)を推定した。

流出範囲の断面積は, B〜B-(1)断面で 5,381 $\mathrm{m}^{2}(2013$ 年 9 月 19 日地下水位), B-(1) B' 断面で $1,534 \mathrm{~m}^{2}(2013$ 年 9 月 19 日地下水位) と推定された. また, 図 7 の赤矢 印の位置において, B〜B-(1)断面, B-(1)〜 B’ 断面に直 交する各月の地下水位差 $1 \mathrm{~m}$ (あるいは $2 \mathrm{~m}$ ) あたりの平面 距離から動水勾配を求めた. なお, B-(1)〜 B’ 断面では, 2013 年 10 月以降は, 観測孔 8B-5 でも水位観測を開始 したため, B-(1)〜B' 断面に直交する観測孔 21B-4 と 8B-5 の距離とこれらの地下水位差から動水勾配を求め た.

そして 3.5 の式(1)より, 各月の地下水流出量を推定す ると, 約 $6,000 \sim 8,300 \mathrm{~m}^{3}$ /日となった (表 2 ).

\section{2 東添道流域の北側流域界}

\subsection{1 流域境界部の地質構造}

図 8 は, 本研究のボーリング調査および既往調査結果を もとに作成した流域界沿いおよび流域界に直交する地 質断面図である. E-E’ 断面, F-F’断面では, 流域界の地 下にも琉球石灰岩が分布し, 基盤の深度は最も低いとこ ろで，標高-14.64m（25B-10）であった。地下水位は $7.12 \mathrm{~m}(2013$ 年 9 月 19 日)で, 帯水層は幅約 $750 \mathrm{~m}$ に存 在し, 層厚さは最大 $21.76 \mathrm{~m}$ あることが判明した。帯水層 の断面形状は，基盤上面の深い西の断層よりで厚くなる 直角三角形であり，流出部分の断面積は 9,455m² (2013 年9月 19 日地下水位) と推定された(E-E’断面(図 8)).

付近の地下水面の傾斜は, 東南東から西南西に傾斜 しており(この傾向は他の時期も同様である) (困 9), 地 下水は東添道流域から西添道流域一流出していると考 えられる。

表 2: 白川田流域の西側流域界北部の流域界において推定された地下水流出量

\begin{tabular}{|c|c|c|c|c|c|c|c|c|c|}
\hline \multirow[b]{2}{*}{ 時期 } & \multirow{2}{*}{ 断面位置 } & \multicolumn{2}{|c|}{ 地下水位標高 $(\mathrm{m})$} & \multirow{2}{*}{$\begin{array}{c}\text { 2点間の距離 } \\
(\mathrm{m})\end{array}$} & \multirow{2}{*}{ 動水勾配 } & \multirow{2}{*}{ 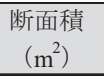 } & \multirow{2}{*}{$\begin{array}{c}\begin{array}{c}\text { 透水係数 } \\
(\mathrm{m} / \mathrm{sec})\end{array} \\
\end{array}$} & \multirow{2}{*}{$\begin{array}{l}\text { 流出量 } \\
\left(\mathrm{m}^{3} / \text { day }\right) \\
\end{array}$} & \multirow{2}{*}{$\begin{array}{c}\text { 合計流出量 } \\
\left(\mathrm{m}^{3} / \mathrm{day}\right)\end{array}$} \\
\hline & & 上流 & 下流 & & & & & & \\
\hline \multirow{2}{*}{ 2013/9/19 } & $\mathrm{B} \sim \mathrm{B}-(1)$ & 13.00 & 12.00 & 200 & 0.0050 & 5381 & $2.26 \times 10^{-3}$ & 5254 & \multirow{2}{*}{6002} \\
\hline & B-(1) $\sim \mathrm{B}^{\prime}$ & 14.00 & 13.00 & 400 & 0.0025 & 1534 & $2.26 \times 10^{-3}$ & 749 & \\
\hline \multirow{2}{*}{ 2013/10/14 } & $\mathrm{B} \sim \mathrm{B}-(1)$ & 13.00 & 11.00 & 400 & 0.0050 & 5381 & $2.26 \times 10^{-3}$ & 5254 & \multirow{2}{*}{6564} \\
\hline & B-(1) $\sim \mathrm{B}^{\prime}$ & $\begin{array}{r}14.41 \\
(21 \mathrm{~B}-4) \\
\end{array}$ & $\begin{array}{r}13.22 \\
(8 \mathrm{~B}-5) \\
\end{array}$ & 272 & 0.0044 & 1534 & $2.26 \times 10^{-3}$ & 1310 & \\
\hline \multirow{2}{*}{$2013 / 11 / 28$} & $\mathrm{~B} \sim \mathrm{B}-(1)$ & 13.00 & 11.00 & 300 & 0.0067 & 5381 & $2.26 \times 10^{-3}$ & 7005 & \multirow{2}{*}{8128} \\
\hline & $\mathrm{B}-(1) \sim \mathrm{B}^{\prime}$ & $\begin{array}{r}14.42 \\
(21 \mathrm{~B}-4) \\
\end{array}$ & $\begin{array}{r}13.40 \\
(8 \mathrm{~B}-5) \\
\end{array}$ & 272 & 0.0038 & 1534 & $2.26 \times 10^{-3}$ & 1123 & \\
\hline \multirow{2}{*}{$2013 / 12 / 22$} & $\mathrm{~B} \sim \mathrm{B}-(1)$ & 13.00 & 11.00 & 300 & 0.0067 & 5381 & $2.26 \times 10^{-3}$ & 7005 & \multirow{2}{*}{8293} \\
\hline & $\mathrm{B}-(1) \sim \mathrm{B}^{\prime}$ & $\begin{array}{r}14.46 \\
(21 \mathrm{~B}-4)\end{array}$ & $\begin{array}{r}13.29 \\
(8 \mathrm{~B}-5)\end{array}$ & 272 & 0.0043 & 1534 & $2.26 \times 10^{-3}$ & 1288 & \\
\hline
\end{tabular}

※東添道流域内の揚水試験の平均値を採用 


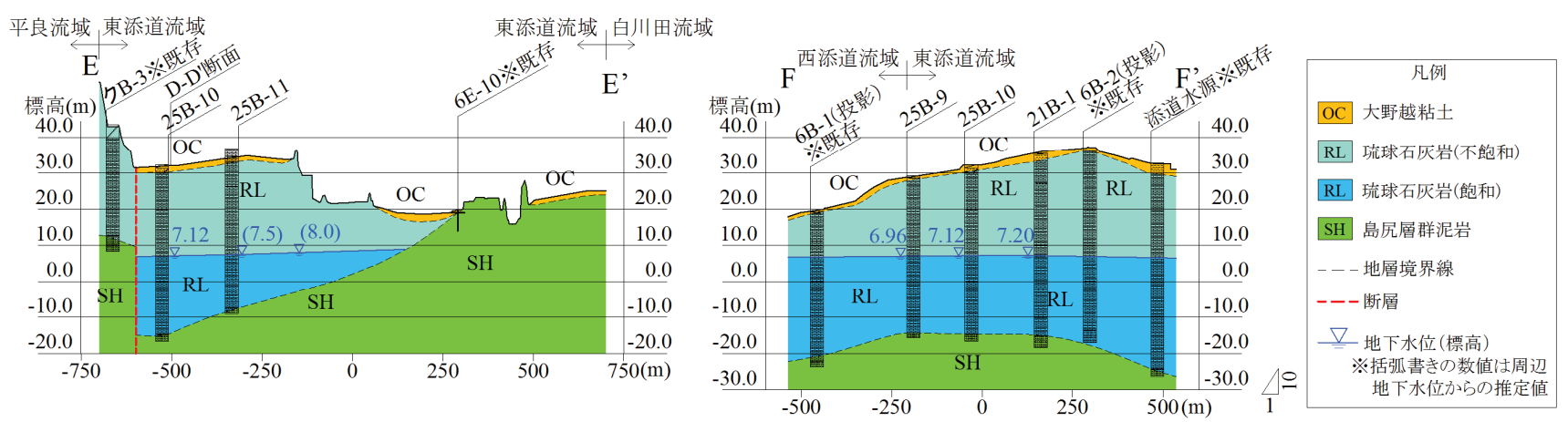

図 8: 東添道流域の北側流域界付近の地質断面図

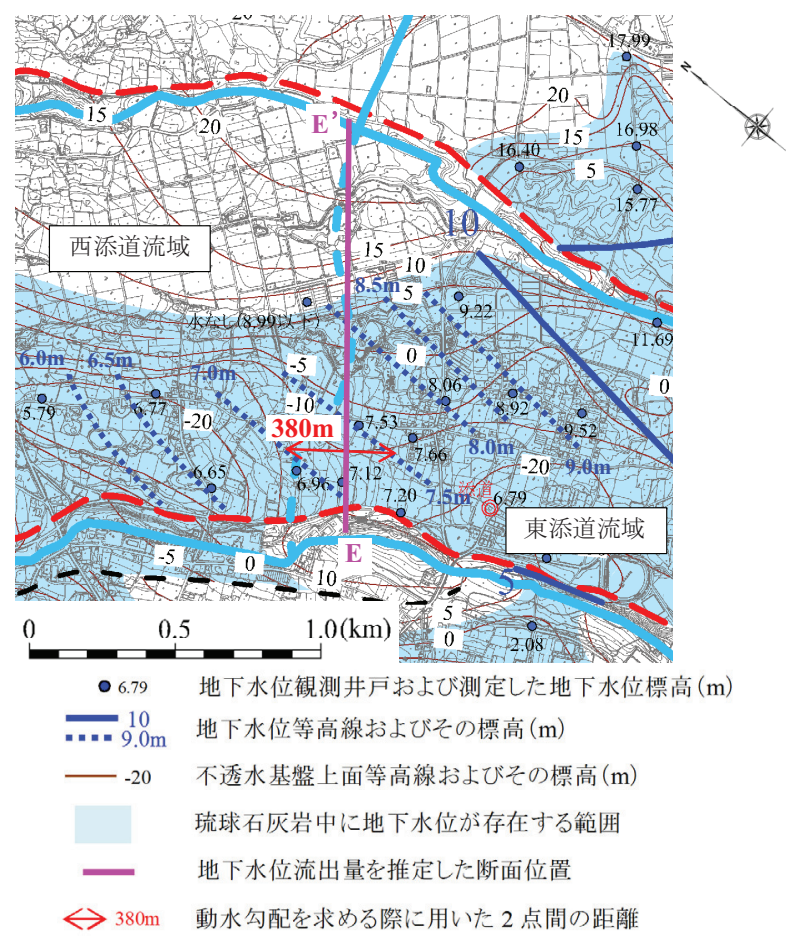

図 9: 東添道流域の北側流域界付近の地下水位等高線 図（2013 年 9 月 19 日）

\subsection{2 東添道流域から西添道流域への地下水流出量}

図 9 赤矢印の位置において, E-E'断面に直交する各月の 地下水位差 $0.5 \mathrm{~m}$ あたりの平面距離から動水勾配を求めた. そして 3.5 の式(1)より, 各月の地下水流出量を求めると, 約 2,100 2,400 $\mathrm{m}^{3}$ /日と推定された(表 3).

流出部の断面積は $9,455 \mathrm{~m}^{2}$ と他の 2 つの範囲に比べ大 きいが, 動水勾配が小さく, 流出量は断面積の割りには少 ない結果となった。

表 3: 東添道流域の北側流域界において推定された地 下水流出量

\begin{tabular}{|c|c|c|c|c|c|c|c|}
\hline \multirow[t]{2}{*}{ 時期 } & \multicolumn{2}{|c|}{$\begin{array}{l}\text { 地下水位 } \\
\text { 標高 }(\mathrm{m}) \\
\end{array}$} & \multirow{2}{*}{$\begin{array}{l}\text { 2点間の } \\
\text { 距離 }(\mathrm{m})\end{array}$} & \multirow{2}{*}{$\begin{array}{l}\text { 動水 } \\
\text { 勾配 }\end{array}$} & \multirow{2}{*}{$\begin{array}{c}\text { 断面積 } \\
\left(\mathrm{m}^{2}\right)\end{array}$} & \multirow{2}{*}{$\begin{array}{c}\text { 透水係数 } * \\
(\mathrm{~m} / \mathrm{sec})\end{array}$} & \multirow{2}{*}{\begin{tabular}{|l} 
流出量 \\
$\left(\mathrm{m}^{3} /\right.$ day $)$
\end{tabular}} \\
\hline & 上流 & 下流 & & & & & \\
\hline $\begin{array}{c}2013 / \\
9 / 19\end{array}$ & 7.50 & 7.00 & 380 & 0.0013 & 9455 & $2.26 \times 10^{-3}$ & 2429 \\
\hline $\begin{array}{l}2013 \\
10 / 14\end{array}$ & 7.00 & 6.50 & 430 & 0.0012 & 9455 & $2.26 \times 10^{-3}$ & 2147 \\
\hline $\begin{array}{l}2013 / \\
11 / 28 \\
\end{array}$ & 7.00 & 6.50 & 400 & 0.0013 & 9455 & $2.26 \times 10^{-3}$ & 2308 \\
\hline $\begin{array}{c}2013 \\
/ 12 / 22\end{array}$ & 7.00 & 6.50 & 400 & 0.0013 & 9455 & $2.26 \times 10^{-3}$ & 2308 \\
\hline
\end{tabular}

\section{3 東添道流域の西側流域界北部}

\subsection{1 流域境界部の地質構造}

図 10 は, 本研究のボーリング調査, 垂直電気探査(図 11) および既往調査結果をもとに作成した流域界の尾根部 (G-G “断面; 断層上盤側) に沿った地質断面図である. G-G’ 断面では, 山稜は琉球石灰岩から成り, 基盤の深度 は $0 \mathrm{~m} \sim 15 \mathrm{~m}$ 付近で波打っており, 最も低い箇所では $0 \mathrm{~m}$ 付近(21E-11)であった. 地下水位は $4.29 \mathrm{~m}$ で, 21E-9 10B-1 付近(幅約 60m と約 200m) と 21B-8 付近 (幅約 $300 \mathrm{~m})$ の 2 つの範囲で基盤が地下水面よりも低い. ここで の帯水層厚は最大で約 $4 \mathrm{~m}$ であることが判明した. また, 流出部分の断面積は北側が $626 \mathrm{~m}^{2}\left(580 \mathrm{~m}^{2}+46 \mathrm{~m}^{2}\right)$, 南側 が $627 \mathrm{~m}^{2}$ と推定された (2013 年 9 月 19 日地下水位).

付近の地下水位は, 東添道流域よりも平良流域の方が 低く(図 12), 地下水は東添道流域から平良道流域一流 出していると考えられる.

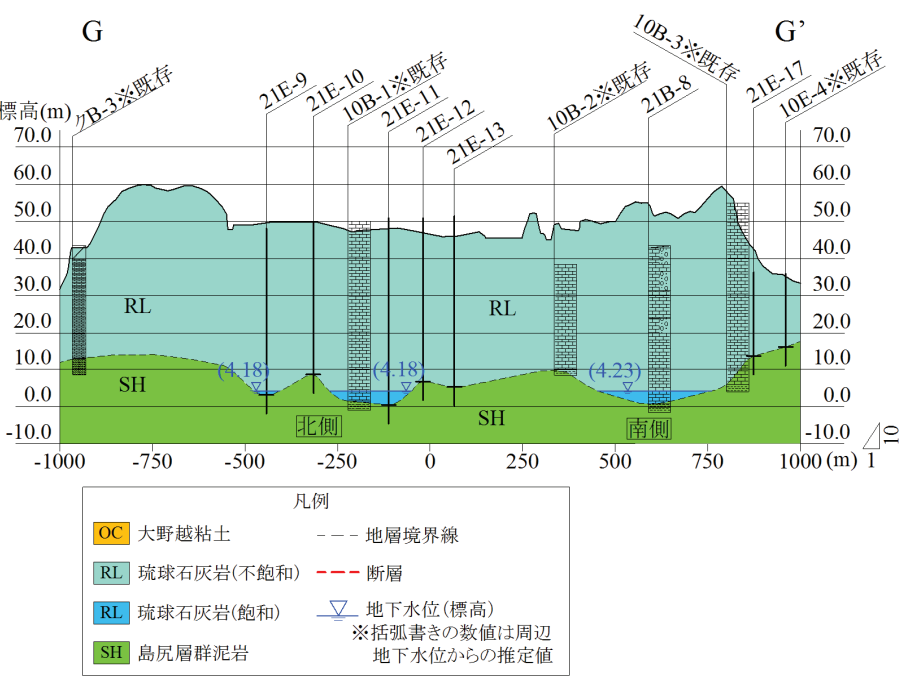

図 10: 東添道流域の西側流域界北部の地質断面図

\subsection{2 東添道流域から平良流域への地下水流出量}

図 12 の北側と南側それぞれの赤矢印の位置において, G-G' 断面に直交する 2 つ井戸の距離とこれらの各月の 地下水位差から動水勾配を求めた. また, G-G’断面では 水深が浅く, わずかな水位変動でも流出部分の断面積の 変化率が大きいため,この流出部分の断面積も各月で算 


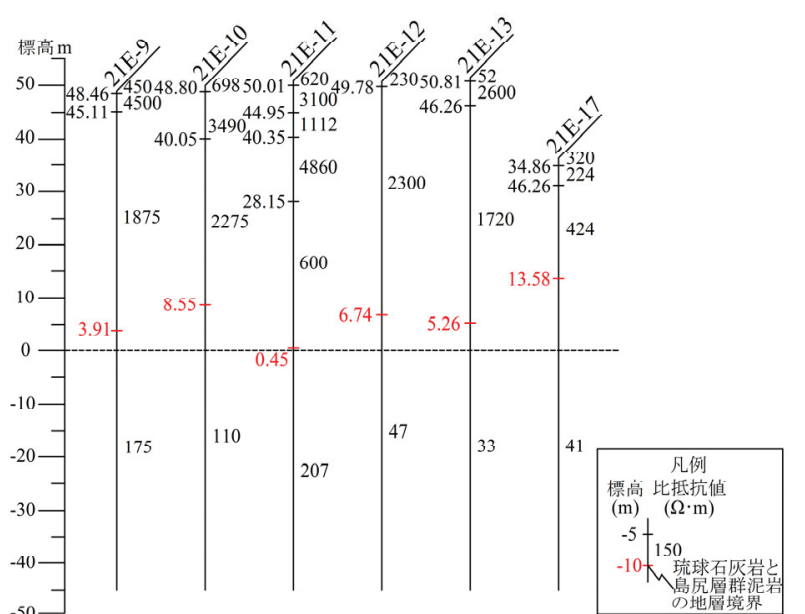

※21E-9, 21E-10, 21E-11 についてはボーリング 10B-1 の基盤上面 が標高 $1.50 \mathrm{~m}$ であることから, 同程度の標高の $207 \Omega \cdot \mathrm{m}$ 以下を島 尻層群泥岩とした。

図 11: 東添道流域の西側流域界北部の垂直電気探 査結果柱状困

出した。

そして, 各月の地下水流出量を 3.5 の式(1)より推定し た.この範囲では南側からの流出量が多く, すべての流出 量を合計すると, 東添道流域加平良流域一の地下水流 出量は約 6,400〜 10,100 $\mathrm{m}^{3}$ / 日と推定された(表 4).

\section{5 まとめ}

- 白川田流域と東添道流域は独立した地下水流域で あるとされていたが, 本研究の結果, 白川田流域の

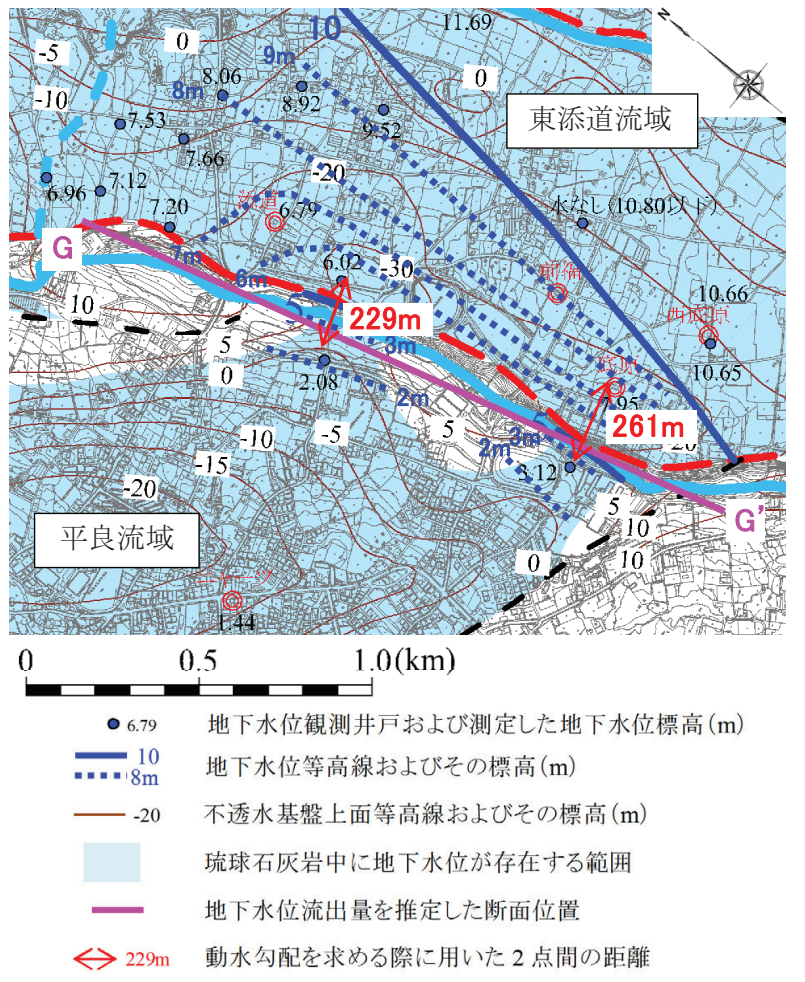

図 12: 東添道流域の西側流域界北部付近の地下 水位等高線図（2013 年 9 月 19 日）

西側流域界北部では, 大野越粘土の下位に帯水層 を成す琉球石灰岩が分布し, また石灰岩中には地下 水面も存在することが確認された. これにより, 2 つの

表 4: 東添道流域の西側流域界北部において推定された地下水流出量

\begin{tabular}{|c|c|c|c|c|c|c|c|c|c|c|}
\hline \multirow[b]{2}{*}{ 時期 } & \multirow[b]{2}{*}{ 流出範囲 } & \multicolumn{2}{|c|}{ 地下水位標高 $(\mathrm{m})$} & \multirow[b]{2}{*}{$\begin{array}{l}2 \text { 点間の } \\
\text { 距離 (m) }\end{array}$} & \multirow[b]{2}{*}{ 動水勾配 } & \multirow[b]{2}{*}{$\begin{array}{l}\text { 流出部地下 } \\
\text { 水位標高(m) }\end{array}$} & \multirow[b]{2}{*}{$\begin{array}{c}\text { 断面積 } \\
\left(\mathrm{m}^{2}\right)\end{array}$} & \multirow{2}{*}{$\begin{array}{c}\text { 透水係数※ } \\
(\mathrm{m} / \mathrm{sec})\end{array}$} & \multirow[b]{2}{*}{$\begin{array}{l}\text { 流出量 } \\
\left(\mathrm{m}^{3} / \text { 日 }\right)\end{array}$} & \multirow[b]{2}{*}{$\begin{array}{c}\text { 合計流出量 } \\
\left(\mathrm{m}^{3} / \text { 日 }\right)\end{array}$} \\
\hline & & $\begin{array}{c}\text { 北側: 12B-1 } \\
\text { 南側 : 底原水源 }\end{array}$ & $\begin{array}{l}\text { 北側: } 8 \mathrm{~B}-7 \\
\text { 南側: } 21 \mathrm{~B}-8\end{array}$ & & & & & & & \\
\hline \multirow{2}{*}{$2013 / 1 / 28$} & 北側 & 6.54 & 2.58 & 229 & 0.0173 & 4.69 & 781 & $4.13 \times 10^{-3}$ & 4813 & \multirow{2}{*}{10143} \\
\hline & 南側 & 8.55 & 5.80 & 261 & 0.0105 & 6.44 & 1418 & $4.13 \times 10^{-3}$ & 5330 & \\
\hline \multirow{2}{*}{$2013 / 2 / 13$} & 北側 & 6.44 & 2.55 & 229 & 0.0170 & 4.62 & 759 & $4.13 \times 10^{-3}$ & 4610 & \multirow{2}{*}{10030} \\
\hline & 南側 & 8.47 & 5.40 & 261 & 0.0118 & 6.11 & 1289 & $4.13 \times 10^{-3}$ & 5420 & \\
\hline \multirow{2}{*}{$2013 / 3 / 8$} & 北側 & 6.25 & 2.28 & 229 & 0.0173 & 4.39 & 688 & $4.13 \times 10^{-3}$ & 4255 & \multirow{2}{*}{9183} \\
\hline & 南側 & 8.10 & 4.60 & 261 & 0.0134 & 5.42 & 1030 & $4.13 \times 10^{-3}$ & 4928 & \\
\hline \multirow{2}{*}{$2013 / 4 / 23$} & 北側 & 6.19 & 2.25 & 229 & 0.0172 & 4.35 & 676 & $4.13 \times 10^{-3}$ & 4151 & \multirow{2}{*}{9109} \\
\hline & 南側 & 8.16 & 4.04 & 261 & 0.0158 & 5.00 & 880 & $4.13 \times 10^{-3}$ & 4958 & \\
\hline \multirow{2}{*}{$2013 / 5 / 24$} & 北側 & 6.58 & 2.62 & 229 & 0.0173 & 4.73 & 794 & $4.13 \times 10^{-3}$ & 4899 & \multirow{2}{*}{8745} \\
\hline & 南側 & 7.69 & 5.37 & 261 & 0.0089 & 5.91 & 1213 & $4.13 \times 10^{-3}$ & 3846 & \\
\hline \multirow{2}{*}{$2013 / 6 / 25$} & 北側 & 6.41 & 2.48 & 229 & 0.0172 & 4.57 & 743 & $4.13 \times 10^{-3}$ & 4553 & \multirow{2}{*}{8327} \\
\hline & 南側 & 7.47 & 4.78 & 261 & 0.0103 & 5.41 & 1026 & $4.13 \times 10^{-3}$ & 3774 & \\
\hline \multirow{2}{*}{$2013 / 7 / 30$} & 北側 & 6.13 & 2.20 & 229 & 0.0172 & 4.29 & 658 & $4.13 \times 10^{-3}$ & 4035 & \multirow{2}{*}{8414} \\
\hline & 南側 & 7.84 & 3.83 & 261 & 0.0154 & 4.76 & 798 & $4.13 \times 10^{-3}$ & 4378 & \\
\hline \multirow{2}{*}{$2013 / 8 / 30$} & 北側 & 6.01 & 2.00 & 229 & 0.0175 & 4.13 & 612 & $4.13 \times 10^{-3}$ & 3822 & \\
\hline & 南側 & 水源地揚水中 & 2.70 & - & - & - & - & $4.13 \times 10^{-3}$ & - & \\
\hline \multirow{2}{*}{ 2013/9/19 } & 北側 & 6.02 & 2.08 & 229 & 0.0172 & 4.18 & 626 & $4.13 \times 10^{-3}$ & 3839 & \multirow{2}{*}{8002} \\
\hline & 南側 & 7.95 & 3.09 & 261 & 0.0186 & 4.23 & 627 & $4.13 \times 10^{-3}$ & 4163 & \\
\hline \multirow{2}{*}{$2013 / 10 / 28$} & 北側 & 5.86 & 1.82 & 229 & 0.0176 & 3.97 & 567 & $4.13 \times 10^{-3}$ & 3562 & \\
\hline & 南側 & 水源地揚水中 & 2.26 & - & - & - & - & $4.13 \times 10^{-3}$ & & \\
\hline \multirow{2}{*}{$2013 / 11 / 28$} & 北側 & 5.78 & 1.65 & 229 & 0.0180 & 3.85 & 534 & $4.13 \times 10^{-3}$ & 3434 & \multirow{2}{*}{6393} \\
\hline & 南側 & 7.48 & 2.26 & 261 & 0.0200 & 3.48 & 415 & $4.13 \times 10^{-3}$ & 2960 & \\
\hline \multirow{2}{*}{$2013 / 12 / 24$} & 北側 & 5.86 & 1.66 & 229 & 0.0183 & 3.89 & 545 & $4.13 \times 10^{-3}$ & 3562 & \\
\hline & 南側 & 水源地揚水中 & 2.35 & - & - & - & - & $4.13 \times 10^{-3}$ & - & \\
\hline
\end{tabular}


流域は繋がっていることが明らかとなった。

- 隣接流域との連結が指摘されていた東添道流域の 北側流域界と西側流域界北部については, 隣接流 域との連結が改めて証明され, 詳細な帯水層の形状 が明らかとなった。

- 各流域界における流出量は以下の通り推定された.

白川田流域の西側流域界北部 (白川田流域力ら 東添道流域一の流出量) : 約 $6,000 \sim 8,300 \mathrm{~m}^{3} /$ 日

東添道流域北部 (東添道流域加西添道流域一 の流出量) : $2,100 \sim 2,400 \mathrm{~m}^{3} /$ 日

東添道流域の西側流域界北部(東添道流域力ら 平良地下水流域 $の$ 流出量）: 約 6,000～ $10,100 \mathrm{~m}^{3} /$ 日

これらの流域外への流出量の合計は, 白川田湧水の湧 水量 (約 $22,000 \mathrm{~m}^{3} /$ 日), または宮古島市が水道水源として 利用している地下水の量 (約 $20,000 \mathrm{~m}^{3} /$ 日) と同程度であり, 水道水源の取水量管理や新規水源開発等を行っていく 上で重要な情報となる。

\section{謝辞}

本研究は,「平成 21 年度宮古島市地下水収支詳細調査業務」, および「平成 $24 \cdot 25$ 年度宮古島市水道水源流域保全調査業務」 として行われたものの一部であり, 調查検討会においてご指導頂 いた元県立石川高等学校校長大城逸朗氏, 元沖縄県企業局技 術技幸喜稔氏, 名桜大学国際学群田代豊教授, 琉球大学渡久 山章名誉教授, 東京農業大学国際食料情報学部中西康博教授, 元琉球大学大学院教授古川博恭氏に厚くお礼申し上げる. また 本稿の公表を許可して頂いた宮古島市上下水道部にはここに感 謝の意を表する。

\section{引用文献}

[1] 今泉真之・前川統一郎・長田実也・富田友幸 (1988): 宮 古島地下ダム計画の水理計算シミュレーションについて, 地下水学会誌, 30(1), pp.11-23. 沖縄総合事務局 八重
山宮古総合農業開発調査事務所 (1982): 宮古島水文地 質図

[2] 古川博恭 (1981) : 九州・沖縄の地下水, 九州大学出版, pp.293-296.

[3] 宮古島市 (2011): 第3次宮古島市地下水利用基本計画, p.52.

[4] 宮古島市 $(2014)$ : 平成 $24 \cdot 25$ 年度 宮古島市水道水源流 域保全調査業務報告書, 第7章, pp.13-28.

[5] 宮古島市上下水道部 (2013): 平成23年度宮古島市地下 水水質保全調查報告書, p.21.

[6] 宮古島市上下水道部 (2016) : 平成28年度宮古島市地下 水水質保全調查報告書, p.32.

[7] 宮古島上水道企業団 (1994a): 上水道施設整備事業地 下水開発工事(底原) 報告書, p.27.

[8] 宮古島上水道企業団 (1994b) : 上水道施設整備事業・地 下水開発工事(ニャーツ) 工事報告書, p.12.

[9] 宮古島上水道企業団 (1995): 白川田・東添道流域内水 源調査委託業務報告書, pp.1-127.

[10] 宮古島上水道企業団（1996a）: 宮古島水道誌 II， pp.189-223, pp329-334.

[11］宮古島上水道企業団 (1996b) : 白川田・東添道流域内水 源調査委託業務報告書, pp.1-37.

[12] 宮古島上水道企業団 (1997)：白川田・東添道流域内水 源調査委託業務報告書, pp.1-101.

[13] 宮古島上水道企業団 (1998a) : 平成10年度東添道流域・ 平良流域界地下水調査委託業務, pp.1-75.

[14] 宮古島上水道企業団 (1998b) : 白川田・東添道流域内水 源調査概要書, pp.1-141.

[15] 森 一司・浅野将人・窪田正和 $\cdot$ 菅原利夫 ·白川俊明・桑 畑英紀 (1997a): 宮古島地下ダム流域に分布する琉球石 灰岩の水文地質学的検討, 地質学雑誌, 103 (5), pp.463-474.

[16] 森 一司・加藤俊典・西田 研・小田友也 (1997b) : 宮古島 砂川地下ダム流域における垂直電気探査の適用牲, 応 用地質, 38(2), pp.54-64.

この論文の公開の質疑または討議は2018年6月30日 まで受付けます。 